REFERENC.ES

Barker, N. W., Nygaard, K. K., Walters, W., and Priestley, J. T. (1940). Proc. Mayo Clin., 15, 769

Brows. Mayo Clin., 15, 769.

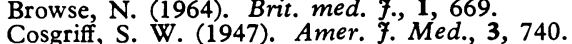

Cosgriff, S. W. (1947). Amer. F. Med., 3, 740.
Felder, D. A. (1949). Surg. Gynec. Obstet., 88, 337.
Gibbs, N. M. (1957). Brit. F. Surg., 45, 209.

Homans, J. (1934). New Engl. f. Med., 211, 993.

- (1947). Ibid., 236, 196.

Pilcher, R. (1939). Lancet, 2, 629.

Sevitt, S., and Gallagher, N. G. (1959). Ibid., 2, 981

- (1961). Brit. F. Surg., 48, 475.

Short, D. S. (1952). Brit. med. F., 1, 790.

\title{
Use of Propranolol in Angina Pectoris
}

\author{
P. M. S. GILLAM,* M.B., M.R.C.P. ; B. N. C. PRICHARD, † M.SC., M.B., B.S
}

Pronethalol, an adrenergic beta-receptor-blocking drug (Black and Stephenson, 1962), has been shown to relieve the pain of angina pectoris in a double-blind trial (Prichard, Dickinson, Alleyne, Hurst, Hill, Rosenheim, and Laurence, 1963). Its use in angina was, however, discontinued following a report of its tumour-producing activity in mice (Paget, 1963). A further disadvantage of pronethalol was that the therapeutic dose was close to that which produced side-effects.

Black, Crowther, Shanks, Smith, and Dornhorst (1964) have described the pharmacology of propranolol (Inderal), a betareceptor-blocking agent in animals and man with about ten times the potency of pronethalol. It is non-carcinogenic in mice and other experimental animals. In view of the effectiveness of pronethalol it was thought that the closely related drug propranolol might be of value in angina. The present paper reports a double-blind trial in out-patients with angina pectoris.

\section{Design of Trial}

The design of the trial closely followed that described by Prichard et al. (1963). The original aim was to compare maximum tolerated doses of propranolol with placebo, but this was modified in that an upper dose limit of $100 \mathrm{mg}$. q.d.s. was later fixed; this dose represented 40 tablets a day. During the "run-in period" the initial dosage was $10 \mathrm{mg}$. q.d.s. Increments of $10 \mathrm{mg}$. per dose per week were made up either to 100 mg. q.d.s. or to the maximum tolerated dose, when this was less. This variable dosage was selected because of the need to take into account individual variability, and also because benefit at a lower dosage might be largely a placebo effect, which may also result from increased frequency of out-patient visits. This latter factor was mitigated by having a long run-in period before the trial proper, three months or more, a period further extended owing to delay in obtaining identically tasting placebo tablets. During this time patients were seen every two weeks and the dosage was adjusted.

The period of the actual trial was eight weeks. Patients were given placebo and propranolol each for two periods of two weeks' duration; they were identical in taste and appearance. Randomization of these four periods was made so that the six possible orders were achieved for every six patients admitted to the trial.

Patients were considered suitable for admission to the trial if they were having at least two typical attacks of angina pectoris each week. The pain had to be of characteristic nature, site, and radiation, brought on by exertion, relieved by rest and

* Formerly Senior Registrar, Medical Unit, University College Hospital, London; now Senior Registrar, Whittington Hospital, London.

† Lecturer in Applied Pharmacology and Therapeutics, Medical Unit, University College Hospital Medical School, London. glyceryl trinitrate, and usually lasting for one to three minutes. The purpose of the trial was explained to the patients, who were told that the new drug would be compared with identical dummy tablets in order to try to eliminate bias. Sixteen patients were started on the run-in period. One 71-year-old woman developed signs and symptoms of heart failure two days after starting $10 \mathrm{mg}$. q.d.s. The drug was stopped; the symptoms cleared without further treatment in three days, as previously reported by Prichard and Gillam (1964). She subsequently experienced an exacerbation of her angina. She has been put on chlorothiazide with potassium supplement and digitalized. Starting as an in-patient, she has been given propranolol again, when she tolerated $50 \mathrm{mg}$. q.d.s. without signs or symptoms of heart failure, with an improvement of her angina. A 63-yearold man developed visual hallucinations after five weeks on $100 \mathrm{mg}$. q.d.s. ; these subsided at a reduced dosage, but his dosage was not readjusted in time for inclusion in the doubleblind trial. The remaining 14 patients entered the trial proper and completed it.

\section{Assessment}

Patients were asked to take glyceryl trinitrate for pain, but not prophylactically, and to record their attacks of angina and glyceryl trinitrate consumption on record sheets that were provided. The sheets were divided into four periods for each day, and patients were asked to fill in their sheet at the end of each period, to record the time of onset of angina, its duration, severity, and the number of glyceryl trinitrate tablets consumed, and to note any comments they desired. Patients were supplied with a known number of tablets, and those taken from the bottle were checked with the number recorded as consumed.

Patients were seen fortnightly by the same clinicians at each visit. The physician who assessed each patient did not know whether propranolol or placebo was being taken and did not refer to previous assessment sheets. Patients were asked standard questions and their subjective impressions recorded.

\section{Results}

The results are summarized in Table I. All 14 patients consumed fewer glyceryl trinitrate tablets and had fewer attacks of pain on propranolol than on placebo. The probability that all 14 patients should produce the same result due to chance is $P=0.00012$, which is highly significant. The subjective reports of the patients were assessed as +2 (much better), +1 (better), 0 (same), -1 (worse), -2 (much worse). The score on placebo was subtracted from that on the drug so that a positive score indicated subjective benefit from propranolol. The maximum score in any patient depended on the number of changes between drug and placebo, which was determined by the 
randomization of the four periods. All 14 patients reported subjective improvement on propranolol $(P=0.00012)$.

\begin{tabular}{|c|c|c|c|c|c|c|c|c|}
\hline \multirow[b]{2}{*}{ Case } & \multirow{2}{*}{$\begin{array}{l}\text { Sex } \\
\text { and } \\
\text { Age }\end{array}$} & \multirow{2}{*}{$\begin{array}{l}\text { Dose } \\
\text { (mg./ } \\
\text { q.d.s.) }\end{array}$} & \multicolumn{3}{|c|}{$\begin{array}{l}\text { Glyceryl Trinitrate } \\
\text { Consumption }\end{array}$} & \multicolumn{2}{|c|}{ Angina Attacks } & \multirow{2}{*}{$\begin{array}{l}\text { Subjec- } \\
\text { tive }\end{array}$} \\
\hline & & & Drug & Placebo & $\begin{array}{c}\text { Ratio } \\
\text { Drug/ } \\
\text { Placebo }\end{array}$ & Drug & Placebo & \\
\hline $\begin{array}{r}1 \\
2 \\
3 \\
4 \\
5 \\
6 \\
7 \\
8 \\
9 \\
10 \\
11 \\
12 \\
13 \\
14\end{array}$ & $\begin{array}{ll}M & 60 \\
M & 60 \\
M & 59 \\
M & 43 \\
M & 63 \\
M & 52 \\
M & 40 \\
F & 65 \\
M & 50 \\
F & 58 \\
M & 45 \\
F & 62 \\
M & 57 \\
M & 67\end{array}$ & $\begin{array}{r}100 \\
100 \\
70 \\
60 \\
70 \\
40 \\
40 \\
100 \\
100 \\
50 \\
100 \\
30 \\
100 \\
60\end{array}$ & $\begin{array}{r}21 \\
22 \\
16 \\
3 \\
29 \\
28 \\
14 \\
5 \\
3 \\
74 \\
203 \\
19 \\
8 \\
1\end{array}$ & $\begin{array}{r}57 \\
41 \\
68 \\
14 \\
50 \\
60 \\
40 \\
26 \\
12 \\
95 \\
302 \\
64 \\
37 \\
30\end{array}$ & $\begin{array}{l:l}1 & : 2 \cdot 37 \\
1 & : 1 \cdot 86 \\
1 & : 4 \cdot 25 \\
1 & : 4 \cdot 67 \\
1 & : 1 \cdot 72 \\
1 & : 2 \cdot 14 \\
1 & : 2 \cdot 86 \\
1 & : 5 \cdot 20 \\
1 & : 4 \cdot 00 \\
1 & : 1 \cdot 28 \\
1 & : 1.42 \\
1 & : 3.37 \\
1 & : 3.85 \\
1 & : 30\end{array}$ & $\begin{array}{r}15 \\
22 \\
16 \\
3 \\
24 \\
28 \\
14 \\
5 \\
3 \\
69 \\
200 \\
18 \\
8 \\
1\end{array}$ & $\begin{array}{r}45 \\
39 \\
68 \\
14 \\
46 \\
59 \\
41 \\
24 \\
12 \\
72 \\
298 \\
46 \\
33 \\
28\end{array}$ & $\begin{array}{l}+3 \\
+2 \\
+4 \\
+3 \\
+4 \\
+3 \\
+5 \\
+2 \\
+1 \\
+2 \\
+2 \\
+6 \\
+2 \\
+1\end{array}$ \\
\hline
\end{tabular}

Side-effects.-The six patients who reached the maximum dosage (100 mg. q.d.s.) had no side-effects. Case 10 had marked bradycardia on $50 \mathrm{mg}$. q.d.s., so that her dose was not increased above this level. The remaining patients experienced the following side-effects at a dosage $10 \mathrm{mg}$. q.d.s. greater than that used in the actual trial (see Table I): (1) transient depression (Case 7) ; (2) giddy and unsteady (Case 6), Case 12 also had similar symptoms but basilar artery insufficiency was suspected and she subsequently had similar symptoms while on placebo ; (3) feeling of irritability (Case 4) ; (4) tiredness (Case 14) ; (5) nausea (Case 3 ); and (6) visual hallucinations-seeing coloured lights (Case 5). In addition two patients had side-effects during the run-in period and were excluded from the trial (see above).

\section{S.G.O.T. and Blood Urea}

In addition to the 14 patients who have completed the trial we have given propranolol to eight hypertensives and two anginal patients for three months or more. The duration of administration of propranolol and the dosage range are summarized in Table II.

Four anginal patients have had readings of elevated S.G.O.T. levels ; all levels were normal when the estimation was repeated, the drug being continued at the same dosage. The total daily dosage in these four patients was $400 \mathrm{mg}$. in two, $280 \mathrm{mg}$. in one, and $120 \mathrm{mg}$. in one.

One mildly hypertensive patient, on $100 \mathrm{mg}$. a day, showed a transiently elevated blood urea, which returned to normal while the drug was continued. One patient with malignant hypertension and very severe angina (Case 11, Table I) has shown a slight elevation of blood urea associated with

TABLE II

\begin{tabular}{|c|c|c|c|c|c|c|c|}
\hline \multirow{2}{*}{\multicolumn{4}{|c|}{$\begin{array}{l}\text { Duration of } \\
\text { Treatment }\end{array}$}} & \multirow{3}{*}{ 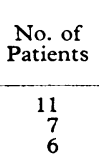 } & \multicolumn{3}{|c|}{ Dosage (mg./day) } \\
\hline & & & & & \multirow{2}{*}{$\begin{array}{c}400 \\
4 \\
3 \\
0\end{array}$} & \multirow{2}{*}{$\begin{array}{c}200-300 \\
6 \\
0 \\
3\end{array}$} & \multirow{2}{*}{$\frac{100-200}{\begin{array}{r}1 \\
4 \\
3\end{array}}$} \\
\hline $\begin{array}{l}9-12 \\
6-8 \\
3-5\end{array}$ & $\begin{array}{l}\text { honths } \\
\text { ", }\end{array}$ & $\begin{array}{l}. \\
\therefore \\
\therefore\end{array}$ & $\begin{array}{l}\ldots \\
\ldots\end{array}$ & & & & \\
\hline & otal & . & . & 24 & 7 & 9 & 8 \\
\hline
\end{tabular}

propranolol administration. Readings of $29 \mathrm{mg} . / 100 \mathrm{ml}$. prior to propranolol, 49 and $45 \mathrm{mg}$. on propranolol, $33 \mathrm{mg}$. on placebo, and $41 \mathrm{mg}$. back on propranolol were obtained. His blood-pressure off propranolol averaged $165 / 115 \mathrm{~mm}$. $\mathrm{Hg}$. supine and $150 / 115$ standing; when on propranolol his pressure averaged $118 / 82$ supine and $112 / 80$ standing. We have had two further hypertensive patients who have recently shown minimal elevations of blood urea while taking propranolol. One patient had a past history of left nephrectomy for renal stones and two operations of nephrolithotomy on the right side, and an intravenous pyelogram showed a scarred right ureter; her most recent blood urea was $40 \mathrm{mg}$. $/ 100 \mathrm{ml}$. The other patient, with angina and hypertension (Case 9, Table I), had bilateral renal artery stenosis, his blood urea remained normal for eight months on propranolol, but the latest reading was slightly raised at $45 \mathrm{mg}$. $/ 100 \mathrm{ml}$. Both of these patients also experienced a fall in blood-pressure with propranolol.

We have not observed any changes in haemoglobin, white-cell count or morphology, platelets, urine analysis, chest $x$-ray picture, or electrocardiogram on propranolol.

\section{Discussion}

Propranolol in the dosage used has been shown to relieve pain in angina pectoris; there was significant benefit in terms of reduced anginal attacks, number of glyceryl trinitrate tablets consumed, and subjective benefit. In the previously reported trial of Srivastava, Dewar, and Newell (1964), a possible benefit of propranolol did not reach the $5 \%$ level of significance. Our trial differs in several important respects from their study. They used a fixed dosage, $20 \mathrm{mg}$. t.d.s., while we altered the dose according to the individual patient, our lowest dose being $30 \mathrm{mg}$. q.d.s. We had a long run-in period-three months being the shortest -during which patients were seen every two weeks to stabilize the well-known beneficial effect of increased hospital attendance and the placebo action of taking tablets, so that the influence of these factors was minimized in the trial proper. Our period of comparison was longer, and the placebo tablets that we used tasted the same as those containing the active drug. It seems likely that some of these factors can account for the different findings. Hamer, Grandjean, Melendez, and Sowton (1964) found that there was an improvement of exercise tolerance after intravenous administration of propranolol in anginal patients.

Propranolol produced a marked subjective improvement, in contrast to our experience with pronethalol (Prichard et al., 1963), and those patients who completed the trial are continuing to take propranolol.

Taking into account the increased potency of propranolol, side-effects are seen at a relatively much higher dosage than with pronethalol, though they are similar in nature. Six of our 14 patients did not experience side-effects at $100 \mathrm{mg}$. q.d.s. and none of our patients experienced side-effects during the trial.

Tsolakas, Davies, and Oram (1964) reported increased transaminase levels after 3 to 12 weeks' propranolol administration at a dosage of 10-20 mg. q.d.s. in 4 out of 18 patients, and these were normal when the test was repeated on placebo. We have found four elevated S.G.O.T. readings in 24 patients given propranolol for three months or more ; however, these have all returned to normal while the drug was continued at the same dosage. This is in accord with the findings of Grant and Green (1964), who reported random elevations of transaminases on both placebo and active drug; moreover, the levels in eight patients were raised on placebo and became normal on propranolol. Kernohan and Neely (1964) also reported random elevation of transaminases on placebo and propranolol in four out of seven patients. It seems unlikely that propranolol causes a rise of transaminase levels, although the possibility should be considered in further trials.

Tsolakas et al. (1964) also reported the cases of two patients on propranolol who had elevated blood ureas, which returned to normal after the drug was stopped. None of the other authors quoted have reported any effect on blood urea. It is likely that the increase of blood urea in the patient with malignant hypertension and angina (Case 11) is due to the hypotensive action of propranolol (Prichard and Gillam, 1964; Prichard, 1965). Our two other patients with elevated blood ureas also had evidence of renal disease. A hypotensive action does not seem to be the explanation with the cases of Tsolakas et al. (1964)-their two patients were normotensive-nor was there any evidence of renal disease (personal communication, 
Oram et al., 1964). The present evidence is such as to warrant observation of blood ureas in patients taking propranolol, though we have not found any rise of blood urea in normotensive patients.

Propranolol is a drug of considerable promise in angina pectoris and worthy of further evaluation. It remains to be determined whether or not such a high dosage is needed for maximum beneficial effect, though a previous trial (Srivastava et al., 1964) at low dosage did not show a significant improvement in angina. The value of intermediate dosage is under investigation. Side-effects are not troublesome. Patients thought likely to develop heart failure should not be given propranolol, though if the subject has not been previously treated with diuretics and digitalis propranolol may be used cautiously after these drugs have been administered.

\section{Summary}

Propranolol was assessed in a double-blind trial in 14 patients with angina pectoris. The maximum tolerated dose, with an arbitrary upper limit of $100 \mathrm{mg}$. q.d.s., was used.

All 14 patients had fewer attacks of angina, consumed fewer glyceryl trinitrate tablets, and were subjectively improved on propranolol $(\mathbf{P}=0.00012)$.

Side-effects were not troublesome with the use of propranolol.
ADDENDUM.-Since this paper was submitted a further trial, in which non-identical placebo tablets were used, has been published (Keelan, P. J. R. B., Brit. med. F., 1965, 1, 897). Unlike that of Srivastava et al. (1964), it did reach accepted levels of significance in favour of the active tablets. The dosage used was $30 \mathrm{mg}$. t.d.s. in all patients.

We are most grateful to Professor M. L. Rosenheim for advice and encouragement and for allowing us to treat his patients. We are indebted to Professor D. R. Laurence for advice in the planning of this trial and to Mr. I. D. Hill, of the M.R.C. Statistical Unit, for statistical advice. We thank Dr. S. A. Stephen, of I.C.I. Pharmaceuticals, for supplies of propranolol and placebo tablets.

\section{REFERENCES}

Black, J. W., Crowther, A. F., Shanks, R. G., Smith, L. H., and Dornhorst, A. C. (1964). Lancet, 1, 1080 - and Stephenson, J. S. (1962). Ibid, 2, 311

Grant, R. H. E., and Green, K. G. (1964). Ibid., 2, 1241

Hamer, J., Grandjean, T., Melendez, L., and Sowton, G. E. (1964). Brit. med. $7 ., 2,720$.

Kernohan, R. J., and Neely, R. A. (1964). Lancet, 2, 1339.

Paget, G. E. (1963). Brit. med. F., 2, 1266

Prichard, B. N. C. (1965), Amer. Heart f., 69, 716.

Dickinson, C. J., Alleyne, G. A. O., Hurst, P., Hill, I. D., Rosenheim, M. L., and Laurence, D. R. (1963). Brit. med. F., 2, 1226.

- and Gillam, P. M. S. (1964). Ibid., 2, 725.

Srivastava, S. C., Dewar, H. A., and Newell, D. J (1964), Ibid, 2,724

Tsolakas, T. C., Davies, J. P. H., and Oram, S. (1964). Lancet, 2, 1064.

\title{
Selective Lymphopenia by Use of Intralymphatic ${ }^{198} \mathrm{Au}$ and Splenectomy
}

\section{Immunosuppressive Action on Rejection of Canine Renal Homografts}

\author{
J. R. WHEELER,* M.D. ; W. F. WHITE, $†$ M.B., B.S., F.F.R. ; R. Y. CALNE, $\ddagger$ M.S., F.R.C.S.
}

Brit. med. F., 1965, 2, 339-342

Selective reduction of lymphocytes is a means of prolonging homograft survival (McGregor and Gowans, 1963). Intralymphatic irradiation of the lymphoid system with ${ }^{131} \mathrm{I}$ and ${ }^{32} \mathrm{P}$ produces selective lymphopenia (Tilak and Howard, 1964 ; A. Syrquin, personal communication). We report our preliminary experience with colloidal radioactive intralymphatic gold, which has greatly depleted the peripheral lymphocyte count and caused severe damage or destruction to the lymph nodes with little effect on the myeloid cells.

\section{Method}

Nineteen adult mongrel dogs ranging from 10 to $20 \mathrm{~kg}$. were anaesthetized with intravenous barbiturate (thiopentone solution $0.5 \mathrm{~g} . / 100 \mathrm{ml}$. or pentobarbitone $30 \mathrm{mg}$. $/ \mathrm{kg}$.).

One millilitre of patent blue violet was injected into the dorsum of the paw between the toes, and the lymphatics were then exposed and isolated $5-10 \mathrm{~cm}$. proximal to the dye injection. Equal volumes of a sterile suspension of colloidal ${ }^{198} \mathrm{Au}$ stabilized with gelatin and $2.8 \% \mathrm{w} / \mathrm{v}$ sodium citrate at $\mathrm{pH} 6-7$ with a particle-size of $200-300 \AA$ (20 millimicrons) ${ }^{1}$ were then injected into the four extremities, using the cannulation method described by Kinmonth (1954). An identical fifth aliquot of

* Research Fellow, Surgical Unit, Westminster Hospital, London. † Senior Registrar, Radiotherapy Department, Westminster Hospital, London.

¥ Senior Lecturer, Surgical Unit, Westminster Hospital, London

₹ Prepared at the Radiochemical Centre, Amersham. colloidal ${ }^{198} \mathrm{Au}$ was injected direct into the mesenteric lymphnodes at the time of splenectomy and renal transplantation. Kidneys were transplanted from unrelated dogs by vascular suture of the renal to the iliac vessels, the ureter being implanted into the bladder. With two exceptions (Dog No. 5, Table I, and No. 9, Table II) the dogs' own kidneys were removed at the same time. The animals were divided into two groups: Group I, colloidal ${ }^{198} \mathrm{Au}$ and splenectomy ; Group II, colloidal ${ }^{198} \mathrm{Au}$, splenectomy, and Imuran (azothioprine) daily from the time of renal transplantation. A third group of nonsplenectomized control animals were treated with Imuran.

Group I (Six dogs).-Dose of colloidal ${ }^{198} \mathrm{Au}$ varied from 25 to $100 \mathrm{mc}$. In four dogs splenectomy, renal transplantation, and mesenteric node injections were performed seven days after the intralymphatic injections; in the remaining 10 animals all procedures were on the same day.

Group II (13 dogs).-Dose of colloidal ${ }^{198} \mathrm{Au}$ varied from 25 to $100 \mathrm{mc}$. In three dogs splenectomy, renal transplantation, and mesenteric node injection were performed seven days after the intralymphatic injections ; in the remaining 10 animals all procedures were on the same day. Imuran was given from the day of renal transplantation at a dose varying from 10 to $2 \mathrm{mg}$./ $\mathrm{kg}$. daily by mouth.

Group III (10 dogs).-These were given . Imuran $10 \mathrm{mg} . / \mathrm{kg}$. for two days, and then $5 \mathrm{mg}$. $/ \mathrm{kg}$. daily by mouth.

The blood urea, white blood cell, and differential counts were performed three times a week. Post-mortem histology was obtained at intervals ranging from 2 to 66 days after the 